\title{
Evaluation of Traditional Medicine Programs In Public Health Centre Mengwi, Bali
}

Ni Made Umi Kartika Dewi

Correspondent Author: nimadeumikartikadewi@gmail.com

Health Science Institute of Medika Persada Bali, Bali, Indonesia

\begin{tabular}{l}
\hline I N D E X I N G \\
\hline Keywords: \\
Evaluation Program; \\
Public Health Centre; \\
Traditional Medicine;
\end{tabular}

Kata Kunci:

Evaluasi Program;

PHC;

Pengobatan Tradisional;

\begin{abstract}
A B S T R A C T
Public Health Centre in Mengwi is one of the Public Health Centre (PHC) that apply traditional medicine program since 2012. However, the result of the program is still under the expected target. This study aims to evaluate the traditional medicine program at PHC in Mengwi. This study was a descriptive evaluation research with qualitative method. Data collection used in-depth interviews with 11 informants. Data analysis was done by thematic analysis using the evaluation method of program (input and process program). The result found in the lack of staff knowledge, this program had not been supported by special funding and facilities. The process of implementation the guidance and visits from PHC in Mengwi had not been done routinely. Traditional in healer has a low level of information about the requirements of making registered permit and registered letters of traditional healer. The availability of inputs on the traditional medicine program at PHC in Mengwi is not optimal yet and the implementation process has not been run maximally. So, it is recommended for local government to use the result of program evaluation as the basis to provide further guidance for health workers and traditional healers.
\end{abstract}

PHC di Mengwi adalah salah satu PHC yang menerapkan program pengobatan tradisional sejak 2012. Namun, hasil dari program ini masih di bawah target yang diharapkan. Penelitian ini bertujuan untuk mengevaluasi program pengobatan tradisional di PHC di Mengwi. Penelitian ini merupakan penelitian evaluasi deskriptif dengan metode kualitatif. Pengumpulan data menggunakan wawancara mendalam dengan 11 informan. Analisis data dilakukan dengan analisis tematik menggunakan metode evaluasi program (input dan proses program). Hasil ditemukan bahwa program ini memiliki pengetahuan staff PHC yang kurang, tidak memiliki dukungan dana yang khusus dan fasilitas yang kurang memadai. Proses pelaksanaan bimbingan dan kunjungan dari PHC Mengwi belum dilakukan secara rutin. Pengobat tradisional memiliki tingkat informasi yang rendah tentang persyaratan pembuatan surat terdaftar dan surat izin praktek pengobatan tradisional. Ketersediaan input pada program pengobatan tradisional di PHC Mengwi belum optimal dan proses pelaksanaannya belum maksimal. Jadi, direkomendasikan bagi pemerintah daerah untuk menggunakan hasil evaluasi program sebagai dasar untuk memberikan panduan lebih lanjut bagi petugas kesehatan dan pengobat tradisional.

(C) 2018 JMMR. All rights reserved

Article History: Received 5 Feb 2017; Revised 15 Sept 2017; Accepted 25 Okt 2017

\section{INTRODUCTION}

Treatment is divided into two major classes, namely modern medicine and traditional medicine. Modern medicine is a scientific treatment ${ }^{1}$, and traditional medicine is treatment by means medicines and healers that refers to experience, hereditary skills or training education, and is applied in accordance with the norms prevailing in society ${ }^{2}$. Traditional medicine consists of a traditional healer who is a person who is recognized or utilized by the community as a person who is able to perform traditional treatment and traditional medicine which is a material or ingredients in the form of plant material, animal material, mineral materials, sari preparations or a mixture of the substance from generation to generation ${ }^{3}$.

In the international world, the development of traditional health services has also received attention from various countries. From the results of the WHO Congress on Traditional Medicine meeting in Beijing in November 2008, it was stated that safe and beneficial traditional health services can be integrated into the health care system and WHO encourages its member countries to develop traditional health services according to local conditions ${ }^{4}$. 
In Indonesia the percentage of traditional medicine use has increased in the last seven years from $15.2 \%$ to $38.30 \%$. In the year 2010 the use of traditional medicine increased very rapidly up to $49.53 \%$ in $2011^{6}$. Increased public interest requires the government to conduct supervision and fostering of traditional healers as an effort to protect the community and anticipate the occurrence of malpractice ${ }^{7}$. As a way of coaching the government has issued a decree of the Minister of Health of the Republic of Indonesia 1076/MENKES/SK/VII/2003 on the Implementation of Traditional medicine. In the regulation, the traditional healers must register themselves to the District Health Office to obtain a traditional healer's permit (SIPT) or a registered letter of traditional healer (STPT) hereby, the practice of traditional medicine can be continuously monitored by the local District Health Office or City, can provide a security guarantee for the community of its users ${ }^{7}$.

Public Health Centre in Mengwi is one of the PHC in Bali implementing traditional health treatment efforts since 2012. This PHC has 65 traditional healers but only $7.7 \%$ of the traditional healers have SIPT and STPT. The low achievement is beyond the expectations of the government that requires traditional healers to have SIPT and STPT. The low ownership of SIPT and STPT on traditional healers raises the question of whether the program has been properly implemented. Besides the program has not been evaluated by the PHC, the low achievement attracts researchers to evaluate this traditional treatment program starting from the input and process conducted by PHC.

\section{RESEARCH METHOD}

This research is a descriptive research with qualitative method. Sampling method was done by purposive sampling technique while data collection on informant was done by in-depth interview consisting of Head of PHC in Mengwi, Holders of traditional medicine program at $\mathrm{PHC}$ in Mengwi, traditional medicine program holder in Badung District Health Office, four traditional healers in work area PHC in Mengwi and four community members who access traditional medicine services. Interview results were analyzed throughout the research process with thematic analysis methods.

\section{RESULT AND DISCUSSION}

Based on the results of the interview can be interpreted that in terms of the availability of traditional treatment program input, $\mathrm{PHC}$ own officers in managing all activities but in terms of quality, the officer did not have the educational background and training in this program. In addition, staff also has the responsibility of holding other programs. In terms of operational financing traditional treatment programs do not have special funds. Current funding is still obtained from other programs. For the facilities and infrastructure needed as a support, the PHC only has books and stickers for traditional healers obtained from personal donations from the Head of the PHC. The PHC has targeted that all traditional healers in the area already have a permit and a registered letter of practice for traditional healers or SIPT and STPT. Based on the results of the interview regarding the program implementation process, the planning has been made well that has been made in accordance with the targets set. Organizational development has been formed through team formation in the mini PHC workshop. In terms of implementation, the program carried out is in accordance with the planning made and the supervision, monitoring and assessment has also been going well by recording and reporting traditional treatment program activities to the Health Office regularly every month.

Based on the results of interviews with traditional healers regarding SIPT or STPT letters, all traditional healers revealed that they did not know the benefits of the letters and some of them did not know how to make them. From the perspective of the community itself the practice of traditional medicine needs to get supervision from the PHC. The results of the interviews found that all informants revealed that there was a need for supervision from the $\mathrm{PHC}$ in order to protect and prevent traditional healers such as fake shamans, lewd shamans and criminal acts and so that traditional healers did not carry out a mall practice.

\section{Input traditional medicine program}

The input component of the traditional medicine program at Mengwi Health Center includes human resources, operational costs, facilities and infrastructure and targets.

\section{Human resources}

Human resources in traditional medicine programs are health workers who have been trained in health and traditional medicine services and are appointed or assigned to manage traditional medicine programs in the PHC area ${ }^{10}$. The availability of labor is seen from two aspects, namely in terms of quantity and quality. In terms of quantity, the PHC already has one program holder who manages all traditional medicine program activities but the program 
holders also hold other programs in the PHC. Whereas in terms of quality, inappropriate educational background of program holders as well as lack of guidance and training obtained from the Health Service led to a lack of knowledge of program holders about traditional medicine programs. The quantity and quality of resources that are lacking can cause less effective implementation of the traditional medicine program.

\section{Cost}

One program input that is very important for a company or organization is the cost ${ }^{11}$. Operational costs are costs needed to carry out and or utilize public health services whose main purpose is to maintain and improve health and to prevent disease ${ }^{12}$. According to the Ministry of Health Regulation No.128/MENKES/SK/III/2004, The implementation of various individual health efforts and public health efforts that are the responsibility of the PHC, need to be supported by the availability of sufficient financing. The main source of funding for PHC is from the Regency or City Government in the form of APBD (Regional Revenue and Expenditure Budget) funds. Based on the results of the evaluation, the staff at PHC said that all traditional treatment programs currently have not received special fees or funding from the District Health Office. The continuity of activities so far still depends on other programs, such as funding the transportation costs to reach the traditional treatment centers, PHC still use funds from other programs. Regarding transportation costs, the Badung District Health Office said that PHC could use BOK funds, which are Activity Operational Assistance funds that could be used for transportation costs for fostering traditional healers in each village. The provision of BOK funds by the government is based on the consideration that the operational costs of PHC are relatively small, because local government budget allocations are more directed towards curative and rehabilitative health efforts. BOK funds can be used to optimize the performance of health workers in the PHC to provide promotion and preventive services ${ }^{13}$.

BOK funds are prioritized on high leverage activities to achieve indicators on the Millennium Development Goals (MDGs) in the health sector. Determination of BOK allocations in PHC is considered based on priority issues, program coverage, geographical conditions, population, and number of health workers. The utilization of BOK funds for PHC activities must be based on the results of the planning agreed upon at the Mini PHC Workshop held regularly according to the conditions of the local area ${ }^{14}$. According to the Head of the PHC for now, BOK funds have not been able to support traditional treatment program activities because BOK funding has been budgeted for other promotion and preventive programs in the PHC.

\section{Facilities}

In an effort to achieve a program in the PHC must be supported by the availability of facilities and infrastructure. Without specific work facilities and infrastructure, the program cannot be completed as it should even experience obstacles. The implementation of a program even though it has clear goals and objectives without adequate facilities and infrastructure resources, the program activities will not be as expected ${ }^{15}$. The facilities and infrastructure needed to support the implementation of traditional medicine programs include monitoring books of the local area of traditional healers, stickers of traditional healers, referral cards and assisted by traditional healers, cover letters to administer STPT or SIPT ${ }^{10}$.

Based on the results of the evaluation of the Mengwi Health Center currently only has a local area monitoring book for traditional healers and traditional healing stickers. Procurement of monitoring books and traditional healer stickers for now is obtained from personal donations from the Head of the PHC. These conditions in general will naturally affect the performance of traditional medicine programs so that the results of their activities become less optimal.

\section{Target}

Every program carried out at the $\mathrm{PHC}$ is equipped with program objectives that cover the target population and targets ${ }^{16}$. Target targets for traditional medicine programs at the Mengwi Health Center ideally include primary targets and secondary targets. Primary targets are traditional healers as providing traditional medicine services in the work area of the Mengwi Health Center and also secondary targets, namely the community as recipients of the traditional medicine services. Based on the results of the evaluation of interviews with the PHC, the target of traditional treatment programs in the working area of the Mengwi Health Center is 65 traditional healers. The target of the traditional healer is to have SIPT or STPT.

Success in traditional medicine programs is very dependent on the availability of various inputs that are appropriate to your needs. Therefore, much attention and effort is needed from the PHC and the District Health Office in fulfilling all the input needs that are still lacking 
in relation to the traditional treatment program activities so that all activities can be carried out properly.

\section{Process of traditional medicine programs}

The management of PHC services, namely for the implementation of various individual health efforts and public health efforts in accordance with the principles of the implementation of the PHC need to be supported by good management of PHC Services. PHC Service Management is a series of activities that work systematically to produce effective and efficient PHC outcomes. A series of systematic activities carried out by the PHC will form management functions. There are several types of management models in PHC, namely PIE (planning, implementation, evaluation), POAC Models (planning, organizing, actuating, controlling), Model P1 - P2 - P3 (planning, implementation, monitoring-controllingassessment), ARRIF model (analysis, formulation, plan, implementation and communication forum) and ARRIME Model (analysis, formulation, plan, implementation, monitoring, evaluation). Of the various management models actually have the same management function. Each PHC is free to determine the management model that it wants to implement ${ }^{17}$.

In the implementation of the traditional medicine program, Mengwi Health Center carried out the PHC management using the P1 (Planning), P2 (MovementImplementation), and P3 (Supervision-MonitoringAssessment) models.

\section{Planning}

Planning is one of the health management functions that must be carried out by the PHC in an effort to achieve the objectives of a program ${ }^{18}$. In general, planning can be said as a systematic preparation process regarding activities that need to be carried out to overcome the problems faced in order to achieve the stated goals. Planning is also a process that starts with formulating the goals of the PHC up to setting alternative activities to achieve it. Without a PHC planning function, there is no clarity on the activities to be carried out by the staff to achieve the PHC goals ${ }^{19}$.

PHC Level Planning (PTP) is a systematic activity process to develop activities in the following year to increase the coverage and quality of health services to the community in an effort to overcome local health problems ${ }^{20}$. The planning in the PHC is divided into two, namely the Proposed Activity Plan (RUK) which is prepared to submit a budget and an Activity Implementation Plan (RPK) which is prepared as a Plan of Action (POA) for the PHC that are involved. The first step in the PHC level planning mechanism is to develop $\mathrm{RUK}^{21}$. The formulation of the RUK PHC must pay attention to various policies that apply both globally nationally and regionally in accordance with the results of the study of data and information available at the PHC. The activity plan must also be completed with financing proposals for routine, facilities, infrastructure and operational needs. The drafted RUK was discussed at the District Health Office. Furthermore, the RUK summarized in the proposal of the District Health Office will be submitted to the DPRD to obtain financing approval and political support. After obtaining approval from the DPRD, then handed it back to the PHC through the District Health Office. Based on the agreement, the PHC prepared RPK. The preparation of the RPK was held in January of the year in the first Mini Workshop forum ${ }^{22}$.

From the results of the evaluation based on interviews with the PHC, the proposed plan of traditional treatment program activities has been made at the beginning of the year in accordance with the targets that have been determined. In the planning stage, the PHC head together with the staff compiles a plan for proposed activities and plans for a proposed budget for traditional treatment programs. After that the proposed activity in the form of RUK was submitted to the Health Office of Badung Regency. The Badung Health Office revealed that the proposed activities and budget from the PHC would be reelected and would later be proposed to the Regional Government Agency (BAPEDA). After the activity is approved by the BAPEDA, the Health Service will hand it back to PHC. Based on the approval of the proposed proposed activities, PHC Mengwi formed an RPK through a Mini Workshop. In the Mini PHC Workshop a fundraising activity can be carried out to obtain cooperation agreements in teams, to determine the division of tasks, responsibilities and designation of activity plans. The work plan that has been agreed upon in the raising can then become a work guideline ${ }^{23}$.

Evaluation results for budget planning for traditional medicine program costs, from the results of interviews with the Head of PHC, the budget plan for traditional treatment programs for now are still not approved by the local government. For budget planning, the PHC revealed that it had planned a proposed fee to the Badung District Health Office, which amounted to Rp. 58,000,000 funding was budgeted for making stickers traditional healer, cards, survey sheets, stationery, transportation funds and socialization costs for socialization for health workers and socialization for traditional healers. The results of 
interviews with holders of traditional treatment programs at the Badung District Health Office confirmed this, the proposed cost plan had been submitted by PHC every year but the local government had not agreed because they were still focused on other preventive and promotion programs.

\section{Movement and Implementation}

Movement and implementation are the second stage in the management function. Mobilization in the implementation of $\mathrm{PHC}$ is a process of mentoring staff so that they are able and willing to work optimally carrying out their duties in accordance with their abilities and skills ${ }^{19}$. while implementation is carrying out activities that have been planned and implemented by the organization or team that has been formed ${ }^{24}$. In the mobilization and implementation of traditional medicine at PHC is carried out in accordance with the planning that has been prepared based on a priority scale that includes the guidance and supervision of traditional healers ${ }^{10}$.

The results of the evaluation of the implementation of traditional treatment program activities at PHC Mengwi showed that the implementation in the field had been carried out every month but the activities carried out were sometimes not in accordance with the plans that had been made in the RPK. This discrepancy is caused by a lack of financial support and transportation equipment owned by PHC so that activities carried out such as coaching to traditional healers must be adjusted to the schedule of other program visits at PHC. The traditional program visit activities are currently carried out together with other cross programs, namely the holders of health and environmental health promotion programs and in collaboration with PHC assistants and local village officials so they have to adjust the schedule together.

\section{Supervision, Monitoring, Assessment}

Supervision and monitoring is a controlling process that is to observe continuously the implementation of activities according to the plan that has been prepared and make improvements if there are irregularities. monitoring in the implementation of PHC activities includes seeing directly, seeing the results of the activity, through reports, and a mini workshop meeting ${ }^{19}$. The benefit of supervision and monitoring is to find out whether the implementation is in accordance with the plan made in the RPK, whether it has constraints or obstacles in implementation, knowing the involvement of staff, cross sectoral and to know the use of the budget and facilities in the implementation of the program $^{24}$. Whereas assessment or evaluating is a process to determine the value or level of success of the implementation of a program in achieving a predetermined goal or an orderly and systematic process in comparing results achieved with benchmarks or criteria that have been determined $^{19}$. As for supervision, monitoring and assessment carried out periodically by PHC for the management of traditional healing activities, it includes recording and reporting activities ${ }^{10}$. The results of the evaluation at the supervision, monitoring and assessment stage of the traditional medicine program, PHC Mengwi has carried out the recording and reporting of all the implementation of traditional medicine program activities to the Health Office regularly every month. However, based on the results of the report it appears that the results are not in accordance with the targets set. There is still a low coverage that most traditional healers who practice in the PHC Mengwi area do not have a practice permit such as not having a SIPT or STPT letter. However, based on the results of the report, the Health Office of Badung Regency has yet to respond and follow up. Interviews with the Badung District Health Office, currently the health department has not been able to follow up because it has not received support from the central government regarding this issue. Whereas in accordance with Government Regulation No. 103 of 2014 concerning "Traditional Health Services" states that the provincial and district governments are responsible for the implementation of traditional medicine. The provincial and district governments are obliged to provide guidance and supervision as well as guarantee traditional health services that are safe for the community by facilitating traditional healers to have SIPT and $\mathrm{STPT}^{26}$.

\section{Traditional healers}

Traditional healers are someone who is recognized and used by the community as a person who is able to perform traditional treatment, whose expertise is acquired from generation to generation, studying, holding or attending education and training ${ }^{3}$. Traditional medicine is divided into 16 types of treatment (Satria, 2013) that is: (1) Acupuncture treatment is stimulation of acupuncture points by inserting needles, electric current (electro acupuncture), heat (moxibustion), lasers (laser acupuncture), or pressure (acupressure). (2) Alexander Technique is a psychophysical reeducation to improve position and coordination. (3) Aromatherapy is the application of essential oils from plants, often accompanied by massage. (4) Autogenic training is autosuggestion or independent hypnosis techniques for relaxation. (5) Flatfoot is a treatment with 
intravenous EDTA for arteriosclerotic disease. (6) Chiropractic is a health care system through the belief that the nervous system plays an important role in health and most diseases are caused by spinal subluxation and can be cured by spinal manipulation. (7) Enzyme therapy is the administration of oral proteolytic enzymes for the purpose of health. (8) Treatment with infusion flowers extracts plants for physical and emotional balance. (9) Herbalism is a treatment with medicinal plants. (10) Homeopathy is a treatment by using the reflection effect of substances that produce symptoms of illness in healthy people. (11) Massage is a treatment by massaging in certain locations. (12) Osteopathy is a therapy by doing massage, mobilization and manipulation. (13) Reflectiology is a treatment using manual pressure to a specific area (especially on the soles of the feet) that is associated with internal organs. (14) Spiritual healing is the channeling of healing energy from a therapist to the patient's body. (15) Tai chi is a physical and mental enhancement using a system of movement and body position. (16) Sports Yoga is a treatment by stretching for respiratory control and meditation.

According to Republic of Indonesia Minister of Health Regulation concerning the Implementation of Traditional Medicine, the classification and type of traditional medicine are divided into four categories, among others 1). Traditional healer skills consist of traditional healers, massage, broken bones, circumcision, dukun, reflection 2) Traditional healers consist of traditional Indonesian herbal medicine (jamu), gurah, physician 3). Traditional healer religious approaches consist of traditional healers with an approach to Islam, Christianity, Catholicism, Hinduism, or Buddhism and 4). The supernatural traditional healer consists of traditional healers in the inner, paranormal and reiky master ${ }^{25}$. Based on these guidelines PHC Mengwi groups traditional healers into two categories according to the expertise and skills of traditional healers in the region, namely are traditional herbal remedy and treatment traditional with skills.

Evaluation results based on interviews with the traditional herbal remedy it was revealed that in providing traditional medicine services they usually treat by giving medicines derived from ingredients such as "tirta" (holy water), oil, and spices from TOGA (Family Medicine Park), while the treatment traditional with skills provides traditional treatment services with massage. The role of PHC in fostering and supervising traditional practitioners includes collecting data on traditional health services in their regions, direct guidance and supervision of traditional healer, giving traditional healer cover letters to manage STPT or SIPT and sending periodic reports to the District Health Office ${ }^{26}$.

Based on the results of the reports made, PHC Mengwi has a low coverage on the target indicators of traditional healers having SIPT and STPT which is only $7.7 \%$ with the target set at $30 \%$. And from the results of interviews with the four traditional treatment informants, only one informant revealed that they already had a SIPT and STPT was assisted by a local PHC assistant while three other informants revealed that they did not have SIPT or STPT and did not have the desire to make that letters. They revealed that they did not know and had not received information from PHC regarding the requirements used to make the SIPT or STPT. In general, the requirements for taking care of SIPT or STPT are very easy such as: Data of traditional healer, photocopy of KTP, certificate from the Village Head where to do work as a traditional healer, recommendations from associations or professional organizations in the field of traditional medicine concerned, photocopy of certificate or certificate of traditional medicine, a local PHC introductory letter, two $4 \times 6 \mathrm{~cm}$ photographic photographs and a map of the business location and floor plan for traditional healers who administer $\mathrm{SIPT}^{25}$.

From the results of the evaluation, it appears that there is still low interest in traditional medicine in having SIPT or STPT and there is still a lack of information provided by the PHC regarding the requirements needed to administer the letters. Whereas according to the Minister of Health Decree No.1076/MENKES/SK/VII/2003 concerning the Implementation of Traditional Medicines, all traditional healers must register with the Head of the District/City Health Office to obtain a Permit or Registered Traditional Medicine (SIPT/STPT). With this, the practice of traditional medicine can continue to be monitored by the local District/City Health Office so that it is hoped that in the end it can provide security guarantees for the user community (ITBI, 2012).

From the results of the evaluation, the informant also revealed that PHC had come about 8 months ago and then provided guidance to continue to develop themselves, gave books and attached stickers to traditional healers and PHC also informed that they would come every month but there was no follow-up. Whereas regular visits, coaching and training from $\mathrm{PHC}$ and from the health services are felt to be very important and can be motivated by informants. Based on the results of the interviews, it appears that traditional medicine program activities, especially in the 
coaching conducted by PHC Mengwi, have not been carried out routinely and optimally.

\section{The community uses traditional medicine}

Traditional medicine is one of the treatments and treatments for other ways outside of medical and nursing sciences, which are widely used by the community in overcoming health problems ${ }^{3}$. Traditional medicine is still in demand by people in Indonesia even though modern health services have developed in Indonesia, the number of people who use traditional medicine remains high $^{27}$. According to the 2001 National Socio-Economic Survey, $57.7 \%$ of Indonesian treated themselves, $31.7 \%$ used traditional medicine, and 9.8 chose traditional medicine 5 . Indonesian people who complain of illness, $65.01 \%$ choose their own treatment using traditional medicine or medicine ${ }^{6}$. Based on the results of evaluation of traditional treatment users at PHC Mengwi the reason for using traditional medical services is because the costs incurred are cheaper, the community is accustomed to using traditional medical services, to find out non-medical or 'niskala' diseases and are more natural without chemicals and effects side.

In order to maintain security for users of traditional medicine PHC Mengwi is obliged to continue to foster the practice of traditional medicine. Such coaching can be carried out with cross-program collaboration, namely with health and environmental health promotion programs. One of the collaborations carried out is by providing guidance in terms of the cleanliness of the behavior of traditional healers and the cleanliness of the environment of traditional medicine practices. The results of the evaluation in terms of hygiene and traditional medicine practice skills, informants revealed that the traditional treatment practices that were accessed were clean and the skills had been good but for the cleanliness of equipment one informant revealed that the equipment used needed to be improved because sometimes the equipment used was like oil for massage still use oil that has smelled and sometimes the oil recommends to be drunk. Based on the results of the interview, the traditional medicine program holders in the PHC need to improve cross-program collaboration not only in terms of hygiene behavior and hygiene practices in the treatment environment but also in the development of facilities and infrastructure used by traditional healers. From the interviews, informants also revealed that the importance of traditional medicine to get guidance and supervision from $\mathrm{PHC}$ is not only able to maintain and provide guidance in terms of cleanliness and skills, but also to protect traditional healers from criminal acts and errors in providing treatment. The need for traditional healers to have registered letters and permits is also felt important for informants to generate trust so that people feel safer to access traditional treatment services.

The evaluation results are similar to the research entitled "The Role of Battra in Traditional Medicine in the Agabag Dayak Community in Lumbis District, Nunukan District". The results of in-depth interviews showed that traditional medicine still had a place besides modern medicine. In principle, the profession of traditional medicine is considered helpful and is still very much needed. The informant in the study had the hope that traditional medicine could still provide treatment. In addition, the informant also hopes that the government can provide assistance to the profession in the form of funding so that they can focus more on the profession as a traditional healer. It is also expected that guidance for traditional healers will improve their knowledge and skills ${ }^{26}$.

\section{CONCLUSION}

Success in this traditional medicine program is highly dependent on the availability of various inputs that support the implementation of the program. Lack of local government support for this program is a major problem in terms of financing. In addition, the objectives that are not achieved from the program are caused by facilities prepared by the PHC that are still not up to standard of traditional medicine programs.

The low interest of traditional healers in making STPT or SIPT due to lack of socialization about the benefits of these letters and the lack of training provided by the relevant health authorities on traditional medicines for both traditional healers and for personnel at the PHC in Mengwi.

This study also obtained that the equipment used by traditional healers can disrupt health. PHC in Mengwi is expected to coach the practice of traditional medicine in terms of hygiene of environmental behavior and the means of equipment used. The need for traditional healers to have registered letters and permits is also felt important for traditional medicine users to generate trust so that people feel safer to access traditional medicine services.

The researcher thanked all the informants who contributed to this research. Fellow lecturers, family and friends for the support provided. 


\section{REFERENCE}

1. Samsunjaya S. Mengenal pengobatan modern dan pengobatan alternatif. Jakarta: Cv. Visindo Medika Persada; 2007.

2. Departemen Kesehatan RI. Manajemen PHC. Jakarta: 2003.

3. Latief A. Obat Tradisional. Jakarta: EGC; 2012.

4. Kementrian Kesehatan RI. Mengenal pelayanan kesehatan tradisional di Indonesia. Direktorat Jendral Kesehat Masy 2011:2011.

5. Lestaridewi NK, Jamhari M. Kajian pemanfaatan tanaman sebagai obat tradisional di Desa Tolai Kecamatan Torue Kabupaten Parigi Mountong. E-JIP BIOL 2017;5:92-108.

6. Supardi S. Penggunaan obat tradisional dalam upaya pengobatan sendiri di Indonesia. Bul Penelit Kesehat 2007;38:80-9.

7. Rahayu DA. Faktor-faktor yang berhubungan dengan pemilihan pengobatan tradisional di wilayah kerja PHC Muara Siberut Kecamatan Siberut Selatan Kabupaten Kepulauan Mentawai Tahun 2012. Alumni Fak Kesehat Masy Univ Andalas 2012.

8. Kusumawati L. Strategi pembinaan pengobatan tradisional untuk menempatkan pengobatan tradisional menjadi salah satu sumber daya pelayanan kesehatan yang diakui. Pus Penelit Dan Pengemb Sist Dan Kebijak Kesehat 2003.

9. Ikatan Terapis Bekam Indonesia. Persyaratan pembuatan surat terdaftar pengobat tradisional (SIPT/STPT) untuk praktek bekam 2011.

10. Dinas Kesehatan Kabupaten Badung. Penduan tehnik penyelanggaraan program pengobatan tradisional. Badung: 2011.

11. Saray D, Karamoy H, Pusung R. Evaluasi anggaran produksi sebagai alat untuk menilai kinerja manajemen pada PT. Manado Media Grafika. J Ekon Manaj Bisnis Akutansi 2014;2:364-73. Satria D. Complementary and alternative medicine (CAM) Fakta atau Janji? Idea Nurs J 2013;IV No. 3.

12. Azwar A. Menjaga mutu pelayanan kesehatan. Jakarta: Pustaka Sinar Harapan; 1996.

13. Pani ME, Trisnantoro L, Zaenab SN. Kesehatan di tiga PHC Kabupaten Ende Provinsi Nusa Tenggara Timur tahun 2011. J Kebijak Kesehat Indones 2012;1:161-7.
14. Aridewi A. Analisis pemanfaatan bantuan operasional kesehatan dalam upaya peningkatan kesehatan ibu dan anak di PHC wilayah kerja dinas kesehatan Kabupaten Kudus. Ejournal Undip 2013;1:32-40.

15. Rahayu T. Evaluasi Pelaksanaan Program Pencegahan dan Penanggulangan Penyakit Demam Berdarah Dengue di Wilayah Kerja PHC Ketapang 2. J Kesehat Masy 2012;1:479-92.

16. Effendi M. Pemanfaatan sistem pengobatan tradisional (BATTRA) di PHC. eJournal .unair 2013.

17. Niah NS. Manajemen Pelaksanaan Pelayanan PHC di Kabupaten Jombang Jawa Timur. JurnalUntagSbyAcId 2015:383-94.

18. Handayani L, Mulasari SA, Nurdianis N, Masyarakat FK, Dahlan UA. Evaluasi program pemberian makanan tambahan anak balita. J Manaj Pelayanan Kesehat 2008;11:21-6.

19. Padila. Buku ajar keperawatan. Nuha Medika; 2012.

20. Peraturan Menteri Kesehatan. Pedoman manajemen PHC. Indonesia: 2016

21. Laeliyah SN, Nadjib M. Hubungan Pemanfaatan Dana Bantuan Operasional Kesehatan (BOK) Dengan Peningkatan Cakupan Kunjungan Antenatal K4 Di PHC Kota Serang Tahun 2014-2016. J Kebijak Kesehat Indones 2017;6:115-26.

22. Departemen Kesehatan RI. Perencanaan tingkat PHC. 2006.

23. Departemen Kesehatan RI. Manajemen PHC. Jakarta: 2003.

24. Farich A. Manajemen pelayanan kesehatan masyarakat. Yogyakarta: Gosyen Publishing; 2012.

25. Keputusan Menteri Kesehatan RI. Penyelenggaran pengobatan tradisional. Indonesia: 2003.

26. Peraturan Pemerintah RI. Pelayanan kesehatan tradisional. Indonesia: 2014

27. Safitri EM, Luthviatin N, Ririanty M. Determinan perilaku pasien dalam pengobatan tradisional dengan media lintah (Studi pada pasien terapi lintah di Desa Rengel Kecamatan Rengel Kabupaten Tuban). Pustaka Kesehat 2016;4:181-7.

28. Dermawan R. Peran battra dalam pengobatan tradisional pada komunitas dayak agabag di Kecamatan Lumbis Kabupaten Nunukan. eJournal Sosiatri-Sosiologi 2013;1:50-61. 